\title{
EFFECT OF DIFFERENT TEMPERATURE AND PH VALUES OF EDTA ON SEALER PENETRATION INTO DENTINAL TUBULES: A PILOT STUDY WITH CONFOCAL LASER SCANNING MICROSCOPE
}

\author{
FARKLI SICAKLIK VE PH DEĞERLERİNDE EDTA KULLANIMININ SEALER \\ PENETRASYONUNA ETKİSİ: LAZER TARAMALI KONFOKAL MİKROSKOP İLE \\ YAPILMIŞ PİLOT ÇALIŞMA
}

\author{
Dr. Öğr. Üyesi Meltem SÜMBÜLLÜ* \\ Prof. Dr. Kezban Meltem ÇOLAK* \\ Prof. Dr. Hakan ARSLAN ${ }^{* *}$
}

\author{
Makale Kodu/Article code: 4690 \\ Makale Gönderilme tarihi: 19.11.2020 \\ Kabul Tarihi: 05.05.2021
}

DOI : $10.17567 /$ ataunidfd.933234

Meltem Sümbüllü: $O R C I D I D: 0000-0002-2647-7988$

Kezban Meltem Çolak: ORCID ID: 0000-0001-5472-677X

Hakan Arslan: ORCID ID: 0000-0003-4890-1062

\section{ABSTRACT}

Aim: The aim of this study was to compare the effect of EDTA with different temperatures and pH values on the penetrability of a sealer into dentinal tubules by the confocal laser scanning microscope.

Materials and Methods: Forty-four single rooted extracted mandibular premolars were used. The working length was determined and then root canals were prepared with the Reciproc system. Before the final irrigation procedures, specimens were randomly distributed into 4 groups according to the temperature and $\mathrm{pH}$ values of EDTA $(n=11): 22^{\circ} \mathrm{C} \mathrm{pH:} 7 ; 22^{\circ} \mathrm{CpH} 12$;

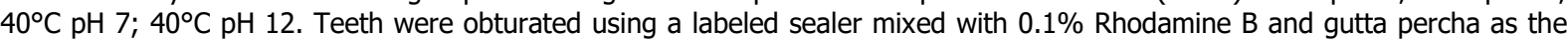
core material. Specimens were then sectioned at 2 and $7 \mathrm{~mm}$ from the apex. All the sections were examined under confocal microscope to calculate the dentinal tubule peneration area. The data were analysed using linear regression analysis and MannWhitney U tests.

Results: The linear regression analysis demonstrated that temperature and area variables had the significant effect on sealer penetration into dentinal tubules $(\mathrm{p}<0.05)$ among the variables (temperature, $\mathrm{pH}$ and area). $22^{\circ} \mathrm{C}$ of EDTA solutions has more penetration area than $40^{\circ} \mathrm{C}$ of EDTA solutions $(p<0.05)$ at the coronal. There were no statistically significantly differences at the apical. When total penetration areas were evaluated, coronal penetration was statistically significantly higher than apical $(\mathrm{p}<0.05)$.

Conclusions: Within the limitation of this study, EDTA at room temperature is more effective than $40^{\circ} \mathrm{C}$ for chelating at the coronal part of the root canals.

Key word: EDTA, Sealer Penetration, pH, Temperature, Surface Tension, Confocal Laser Scanning Microscope.

öz

Amaç: Bu çalışmada son yıkama solüsyonu olarak farklı sıcaklık ve pH değerlerinde EDTA kullanımının sealer penetrasyonuna etkisinin lazer taramalı konfokal mikroskop ile değerlendirilmesi amaçlanmaktadır.

Gereç ve Yöntem: Çalışmada 44 adet çekilmiş, tek köklü ve tek kanallı alt premolar diş kullanıldı. Dişlerin çalışma uzunluğu belirlendikten sonra kemomekanik preparasyonları resiprok sistem ile tamamlandı ve son irrigasyon aşamasında EDTA'nın sıcaklık ve pH değerlerine göre dişler 4 gruba ayrıldı $(n=11)$ : Grup 1: $22^{\circ} \mathrm{C} \mathrm{pH:} \mathrm{7;} \mathrm{Grup} \mathrm{2:} 22^{\circ} \mathrm{CpH} 12$; Grup 3: $40^{\circ} \mathrm{C} \mathrm{pH} \mathrm{7;} \mathrm{Grup}$ 4: $40^{\circ} \mathrm{C} \mathrm{pH}$ 12. Dişler $\% 0.1$ Rhodamine B ile işaretlenmiş kanal patı ve guta perka ile dolduruldu. Kökün apikal kısmından 2 ve 7 mm uzaklıktan horizontal kesitler alındı. Örnekler Lazer Taramalı Konfokal Mikroskop ile incelendi ve patların dentin tübüllerine penetrasyon alanı hesaplandı. Verilerin istatistiksel analizinde; linear regresyon analizi ve Mann-Whitney U testi kullanıldı.

Bulgular: Linear regresyon analizi ile EDTA'nın sıcaklığının ve kesitin alındığı yerin sealer penetrasyonuna etkisi olduğu gösterildi $(p<0.05) .22^{\circ} \mathrm{C}$ EDTA solüsyonu, $40^{\circ} \mathrm{C}$ EDTA solüsyonuna göre koronal üçlüde istatistiksel olarak daha fazla penetrasyon alanı sağladı $(p<0.05)$. Apical üçlüde ise EDTA'nın sıcaklığına bağlı olarak herhangi bir istatistiksel farklılık gözlemlenmedi. Total penetrasyon alanları karşılaştırılığında, koronal penetrasyon alanı apikal penetrasyon alanından istatistiksel olarak daha fazlaydı $(\mathrm{p}<0.05)$.

Sonuç: Oda ISIsındaki EDTA solüsyonu, $40^{\circ} \mathrm{C}^{\prime}$ deki EDTA solüsyonuna göre, kök kanalının koronal üçlüsünde daha fazla penetrasyon alanı sağlar.

Anahtar Kelimeler: EDTA, Selaer Penetrasyonu, pH, Sıcaklık, Yüzey Gerilimi, Lazer Taramalı Konfokal Mikroskop.

*Atatürk Üniversitesi Diş Hekimliği Fakültesi Endodonti Anabilim Dalı, Erzurum.

** İstanbul Medeniyet Üniversitesi Diş Hekimliği Fakültesi, Endodonti Anabilim Dalı, İstanbul

Kaynakça Bilgisi: Sümbül M, Çolak KM, Arslan H. Farklı sıcaklık ve pH değerlerinde EDTA kullanımıın sealer penetrasyonuna etkisi: lazer taramalı konfokal mikroskop ile yapıImış pilot çalışma. Atatürk Üniv Diş Hek Fak Derg 2021; 31: 379-84.

Citation Information: Sumbul M, Colak KM, Arslan H. Effect of different temperature and $\mathrm{pH}$ values of EDTA on sealer penetration into dentinal

tubules: a pilot study with confocal laser scanning microscope. J Dent Fac Atatürk Uni 2021; 31: 379-84. 


\section{INTRODUCTION}

Root canal treatment includes chemomechanical procedures and three-dimensional impermeable filling of the canal system ${ }^{1,2}$. Due to the limited penetration depths of conventional root canal irrigation solutions, dentin tubules can not be cleaned effectively ${ }^{3-5}$. Bacteria are able to remain viable within dentinal tubules creating a reservoir of residual infection ${ }^{6}$. On the smear removed surface, the sealer penetrates into the dentinal tubules and provides a mechanical lock between the sealer and root dentin ${ }^{7}$. Mechanical lock can eliminate leakage pathways from the coronal and apical directions and entomb remaining bacteria in the root canal ${ }^{8}$. Canal sealer also prevents re-infection due to its antibacterial properties ${ }^{9}$.

For effective disinfection, irrigation solutions should be in direct contact with the dentin wall and debris in the canal ${ }^{10}$. Increasing the contact depends on the wettability of the surface by the solution, and wetting of the surface by the solution depends on the surface tension ${ }^{10-12}$. Surface tension can be defined as the gravitational force between molecules, and this force prevents the liquid from spreading on the surfa$\mathrm{ce}^{11}$. Yilmaz et al. ${ }^{1}$ showed that surface tension of EDTA was significantly influenced by temperature and $\mathrm{pH}$.

To our knowledge, no study has been made of the dentinal tubule penetration of sealer with different temperature and $\mathrm{pH}$ values of EDTA. The aim of this study was to evaluate the effect of EDTA used at different temperature and $\mathrm{pH}$ values on the sealer penetration into dentin tubules using a confocal laser scanning microscope.

\section{MATERIALS AND METHODS} Selection of teeth

The study method was approved by the Ethics Committee of Ataturk University, Faculty of Dentistry, Erzurum, Turkey. The decision number of the ethical approval was 2016-09. This study included 44 singlerooted human teeth with single root canal, fully developed apex and with no fractures or cracks that had been extracted due to orthodontic and periodontal reasons. The collected teeth were kept in physiological saline solution until use. Soft and hard tissue residues around the pulled teeth were removed by ultrasonic devices. The teeth were examined under a stereomicroscope for any fractures or cracks. Radiographs of the facial and proximal dental surfaces were obtained to verify that the teeth were single root canal. Teeth with a completely formed apex and without previous root fillings, resorptions, or calcifications were used in the study.

\section{Preparation of the EDTA solution}

The $\mathrm{pH}$ value of $17 \%$ EDTA solution (Saver, Prime Dental, India) was measured and determined to be 12 . The solution was buffered with $\mathrm{HCl}$ to obtain an EDTA solution with $\mathrm{pH}$ 7. Neutral $\mathrm{pH}$ stability was checked with a pH meter (S200 Seven Compact, Mettler Toledo, Switzerland) after 5, 15, 60, and 180 $\min$.

A syringe warmer system (CanalPro Syringe Warmer, Coltene, Langenau, Germany) was used to adjust the temperature of the EDTA solution at $40^{\circ} \mathrm{C}$. The injector temperature was controlled using an infrared remote temperature measuring device (Medisana, Neuss, Germany) according to the manufacturer's recommendations.

\section{Preparation of the root canals}

Endodontic access was obtained and the working length was determined by subtracting $1 \mathrm{~mm}$ from the distance to the apical foramen using a $20 \mathrm{~K}$ type file (Dentsply, Maillefer). All the root canals were prepared using Reciproc R40 files according to the manufacturer's recommendation. The R40 files were used in the "RECIPROC ALL" mode using a Silver Reciproc (VDW, Munich, Germany) endodontic motor. After three pecking motions, irrigation was performed with $1 \mathrm{ml}$ of $2 \% \mathrm{NaOCl}$ (Chloraxid; Cerkamed, Stawola Wola, Poland) using a 30-gauge, closed-ended irrigation needle. At the final irrigation stage $5 \mathrm{ml}$ of $2 \% \mathrm{NaOCl}$ was used and the teeth were then randomly divided into four group according to different temperature and $\mathrm{pH}$ values of EDTA, as follows $(\mathrm{n}=11)$;

$22^{\circ} \mathrm{C} \mathrm{pH}=7 ; 22^{\circ} \mathrm{C} \mathrm{pH}=12 ; 40^{\circ} \mathrm{C} \mathrm{pH}=7 ;$ $40^{\circ} \mathrm{C} \mathrm{pH}=12$. For each groups root canal irrigated with $5 \mathrm{ml}$ EDTA for 1 minute.

\section{Filling the root canals}

The canals were washed with $5 \mathrm{ml}$ of distilled water to avoid residual irrigation solution in the root canal system. The root canals were dried with sterile paper points (Dentsply Maillefer) before filling. For fluorescence under confocal laser scanning microscopy, 2seal root canal sealer (VDW, Munich, Germany) was mixed with $0.1 \%$ fluorescent rhodamine $B$ isothiocyanate (Bereket Chemical Industry, Istanbul, Turkey). The paste/rhodamine $B$ ratio was determined by a preliminary pilot study $(0.5 \mathrm{~g}$ sealer $/ 70 \mu \mathrm{l}$ of 
rhodamine B). A Reciproc R40 Gutta-Percha (VDW, Munich, Germany) cone was then lightly coated with the labeled rhodamine B-sealer mixture and placed in the root canal to the working length. Lateral condensation was performed, and root canal filling was completed. The cavity was filled with a temporary filling material (Cavit 3M; ESPE, St. Paul, MN), and the specimens were stored at $100 \%$ humidity, $37^{\circ} \mathrm{C}$ for 1 week to completely set.

\section{Analysis}

Confocal Laser Scanning Microscope

After the root canal sealer had set, each specimen was sectioned perpendicular to its long axis using a precision saw (IsoMet 1000; Buehler, Lake Bluff, IL) at a slow speed under water cooling. Two slices were obtained from each tooth at depths of 2 and $7 \mathrm{~mm}$ (apical and coronal) from the apex and approximately $1 \mathrm{~mm}$ thickness. The sections were polished with silicon carbide abrasive paper. In each experimental group, 22 samples were obtained from 11 different teeth.

The samples were then mounted onto glass slides and examined using a confocal laser scanning microscope (Zeiss LSM 710, Germany) at 10x with a wavelength of 560-600 nm. In cases where the entire canal could not examined in one image, further partial images were taken and then assembled as a single image using Photoshop (Adobe Systems, Inc., San Jose, CA).

For calculate the penetration area, the method described in previous studie was used 13. Digital images were imported into the Image] program (Image] software, NIH) to measure the total dentinal tubule penetration area. The dentinal tubule penetration area was measured in micrometres $(\mu \mathrm{m})$ and converted to square millimetres $(\mathrm{mm} 2)$ for the statistical analysis.

\section{Statistical analysis}

A linear regression analysis was used to determine the variables (temperature, $\mathrm{pH}$ and area) that best correlated with sealer penetration into dentinal tubules. Data were statistically analysed using the Mann-Whitney $U$ tests, and $p<0.05$ was set as significant.

\section{RESULTS}

The images obtained with CLSM are shown in the figure 1 . The linear regression analysis demonstrated that temperature and area had the significant effect on sealer penetration into dentinal tubules $(p<0.05)$ (Table I). It was shown that $\mathrm{pH}$ variable had no effect on sealer penetration ( $p>0.05)$. Mann Whitney $U$ test for temperature at the coronal and apical thirds are presented in Table 2 and 3.

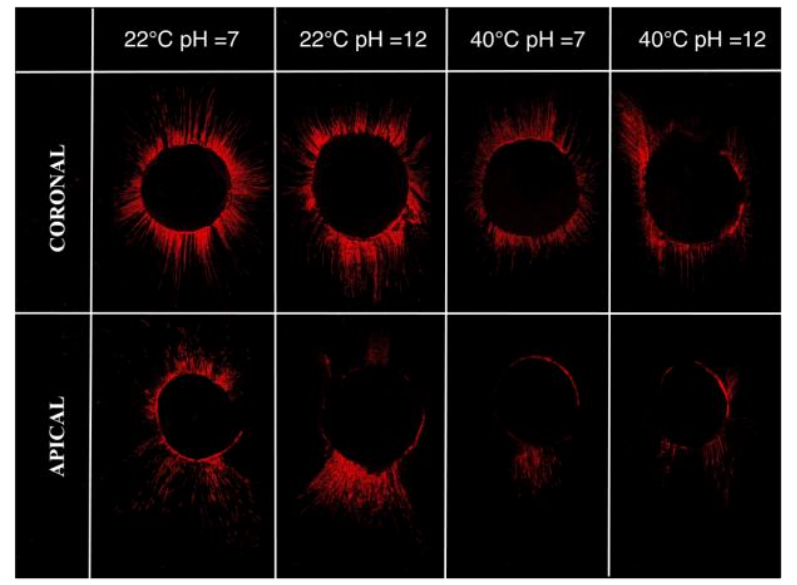

Figure 1. Confocal laser scanning microscopic images from each group at coronal and apical thirds.

Coronal third: It was shown that dentinal tubule penetration area values were significantly affected by the temperature of EDTA $(p<0.05) .22^{\circ} \mathrm{C}$ of EDTA solutions has more penetration area than $40^{\circ} \mathrm{C}$ of EDTA solutions $(p<0.05)$. When total penetration areas were evaluated, coronal penetration was statistically significantly higher than apical penetration $(p<0.05)$. (Table IV).

Apical third: There were no statistically significantly differences between different temperatures at the apical third.

Table 1. Linear regression analysis findings determine the variables (temperature, $\mathrm{pH}$ and area) that best correlated with sealer penetration into dentinal tubules

\begin{tabular}{lcccc}
\hline & B* & Standard error & Beta & $P$ value \\
\hline Temperature & -0.023 & 0.009 & -0.181 & .007 \\
pH & -0.006 & 0.009 & -0.044 & .502 \\
Area & -0.100 & 0.009 & -0.775 & .000 \\
\hline
\end{tabular}

Table 2. The mean and standard deviation values of dentinal tubule penetration area $\left(\mathrm{mm}^{2}\right)$ of coronal third of root canals.

\begin{tabular}{ccc}
\hline Groups & $\mathrm{n}$ & Mean \pm SD \\
\hline $22^{\circ} \mathrm{C}$ & 22 & $0.082 \pm 0.067$ \\
$40^{\circ} \mathrm{C}$ & 22 & $0.046 \pm 0.055$ \\
\hline
\end{tabular}

Table 3. The mean and standard deviation values of dentinal tubule penetration area $\left(\mathrm{mm}^{2}\right)$ of apical thirds of root canals.

\begin{tabular}{ccc}
\hline Groups & $\mathrm{n}$ & Mean $\pm \mathrm{SD}$ \\
\hline $22^{\circ} \mathrm{C}$ & 22 & $0.020 \pm 0.030$ \\
$40^{\circ} \mathrm{C}$ & 22 & $0.007 \pm 0.015$ \\
\hline
\end{tabular}


Table 4. The mean and standard deviation values of total dentinal tubule penetration areas $\left(\mathrm{mm}^{2}\right)$ according to the coronal and apical thirds.

\begin{tabular}{ccc}
\hline & $\mathrm{n}$ & Mean \pm SD \\
\hline Coronal & 44 & $0.108 \pm 0.010$ \\
Apical & 44 & $0.007 \pm 0.002$ \\
\hline
\end{tabular}

\section{DISCUSSION}

The success of root canal treatment depends on the removal of microorganisms from the infected root canal and the prevention of their reproduction ${ }^{14}$. After chemomechanical preparation, bacteria may still be detected in the root canal system ${ }^{15}$. Previous studies showed that the smear layer covers the dentin surface and prevents penetration of the sealer into the tubules ${ }^{16,17}$. The thickness of the smear layer varies between 1-5 $\mu \mathrm{m}$, the part inside the dentin tubules can reach up to $40 \mu \mathrm{m}{ }^{18}$. The amount of canal sealer that penetrates dentinal tubules can serve as an indicator the effectiveness of smear layer removal ${ }^{19}$. Previous research showed that irrigants with low surface tension penetrated dentinal tubules and anatomical irregularities 20,21 .

Ethylenediaminetetraacetic acid (EDTA) is an effective chelating agent that is frequently used in endodontic treatment 22,23 . The efficacy of EDTA, considered as the gold standard for removal of the smear layer, varies depending on the application time, temperature, $\mathrm{pH}$, and concentration 22,24-26. Heating the EDTA solution reduces the surface tension and increases the wettability of dentin 21,27 . One study showed that EDTA heated to $37^{\circ} \mathrm{C}$ had superior wetting ability due to reduced surface tension 1. Another study reported that EDTA solution effectively removed the smear layer at $25^{\circ} \mathrm{C}$ and $37^{\circ} \mathrm{C}$ in the coronal, middle, and apical thirds ${ }^{26}$. In the same study, the sealer penetration area was reduced in which the solution was heated to $40^{\circ} \mathrm{C}$. Zehnder and Paque ${ }^{28}$ showed that the effects of chelating agents varied at different temperature ranges, and EDTA binding of calcium decreased when the solution temperature was increased from $20^{\circ} \mathrm{C}$ to $90^{\circ} \mathrm{C}$. The aforementioned finding may explain why less sealer penetration area was observed at high temperature in the present study.

The demineralization effect of EDTA is better at pH 5-6 ${ }^{29}$. However, EDTA solutions often have high $\mathrm{pH}$ values and exhibit a reduced tendency to chelate with calcium ions at high $\mathrm{pH}$ values ${ }^{30,31}$. At high $\mathrm{pH}$ values, the excess number of hydroxyl groups slow down and dissolution of hydroxyapatite decrease due to limited calcium binding. Although it seems that there is a differences between different $\mathrm{pH}$ values of EDTA solutions, according to our study it was shown that there is no statistically significantly differences between $\mathrm{pH} 7$ and 12 of EDTA solutions in terms of sealer penetration.

The present study examined sealer penetration at EDTA temperatures of $22^{\circ} \mathrm{C}$ and $40^{\circ} \mathrm{C}$. Some studies suggested that temperatures approximately $10^{\circ} \mathrm{C}$ above the normal body temperature (i.e., $37^{\circ}$ C) could damage the periodontal ligament 32 . Therefore, the temperature values of EDTA in the present study were $22^{\circ} \mathrm{C}$ (i.e., room temperature) and $40^{\circ} \mathrm{C}$, as used in previous studies.

Previous studies on canal sealers and filling techniques reported a decrease in penetration areas from the coronal to the apical 9,33,34. The authors of these studies attributed the decrease in sealer penetration toward the apical to a number of factors, including a higher number of dentin tubules in the coronal and middle thirds, as well as larger tubul diameter. Other suggested reasons were increased compression forces during root canal filling at the coronal and middle thirds and increased sclerosis and mineralization at the apical part ${ }^{2}$. Furthermore, some studies noted that it was difficult to deliver irrigation solution to the apical portion and that there was less tubular structure of dentin in this region ${ }^{35}$. In the present study, tubular structure may explain the reduced penetration in the apical region

Light microscopy, scanning electron microscopy (SEM), and laser scanning confocal microscopy (CLSM) can be used to assess sealer penetration into dentinal tubules $16,33,36$. CLSM has a number of advantages as compared with other imaging methods. CLSM allows image acquisition by diffusing a laser beam into the dentin, enamel, and biofilm ${ }^{37}$. In previous studies, CLSM was used to evaluate the penetration of sealers into dentin tubules, to compare filling techniques, and to evaluate the effectiveness of various irrigation solutions and irrigation techniques in endodontics ${ }^{33}$. Via laser beam diffusion in CLSM, two-dimensional images of dentin, enamel, and biofilms can be obtained ${ }^{37}$. It is more advantageous than the other techniques because it does not require special sample preparation processes ${ }^{38}$. Samples can be reused after CLSM because they are not damaged ${ }^{39}$. In contrast to CLSM, SEM provides high-quality images of dentin tubules and sealer. However, a disadvantage of SEM is 
that human teeth must be dried, treated with alcohol, and observed under high vacuum. These sample preparation steps lead to loss of material, including the root canal seal ${ }^{36}$. SEM studies are also assessed using a scoring system, which can lead to subjective evaluations of the data obtained ${ }^{39}$.

Images in CLSM are obtained by the fluorescence of rhodamine $B$ dye mixed with the sealer. The addition of the dye does not change the physical properties of the sealer ${ }^{34}$. Gharib et al. ${ }^{8}$ added various concentrations rhodamine $B$ to sealer and stated that a concentration higher than $0.1 \%$ caused excessive fluorescence in images. In our preliminary pilot study, sealer was mixed with rhodamine B $(0,1 \%)$ in different ratios, and the optimal sealer/rhodamine $B$ mixture suitable for use at a wavelength of $560 \mathrm{~nm}$ (i.e., where CLSM works optimally) was used.

Image] program was used to evaluate the total penetration area. This program works according to the user's choices and can calculate the area of an object and the pixel value according to the density. Gharib et al. ${ }^{8}$ calculated the ratio inside the lines drawn around the canal walls and sealer penetration area. However, this method does not take the intensity of the penetration area into account, this may affect the results.

\section{CONCLUSION}

In the present study, effect of EDTA with different temperature and $\mathrm{pH}$ values on sealer penetration into dentinal tubules was studied. Statistical analysis demonstrated that temperature and area has the significant effect on sealer penetration, but $\mathrm{pH}$ variable has no effect. According to the findings of the present study, EDTA at room temperature is more effective than $40^{\circ} \mathrm{C}$ for chelating at the coronal part of root canals.

\section{Acknowledgements}

The authors declare that there were no other contributors involved in this work.

\section{REFERENCES}

1. Yılmaz Z, Aktemur S, Buzoglu HD, Gümüsderelioglu $M$. The effect of temperature and $\mathrm{pH}$ variations on the surface tension of EDTA solutions. J Endod 2011;37:825-27.

2. Kuçi A, Alaçam T, Yavaş Ö, Ergul-Ulger Z, Kayaoglu G. Sealer penetration into dentinal tubules in the presence or absence of smear layer: a confocal laser scanning microscopic study. J Endod 2014;40:1627-31.
3. Peters OA. Current challenges and concepts in the preparation of root canal systems: a review. ] Endod 2004;30:559-67.

4. Peters $O A$, Schönenberger K, Laib A. Effects of four $\mathrm{Ni}-\mathrm{Ti}$ preparation techniques on root canal geometry assessed by micro computed tomography. Int Endod J 2001;34:221-30.

5. de Paz LC. Redefining the persistent infection in root canals: possible role of biofilm communities. J Endod 2007;33:652-62.

6. Peters L, Wesselink P, Buijs J, Van Winkelhoff A. Viable bacteria in root dentinal tubules of teeth with apical periodontitis. J Endod 2001;27:76-81.

7. Haragushiku GA, Sousa-Neto MD, Silva-Sousa YT, Alfredo E, Silva SC, Silva RG. Adhesion of endodontic sealers to human root dentine submitted to different surface treatments. Photomed Laser Surg 2010;28:405-10.

8. Gharib SR, Tordik PA, Imamura GM, Baginski TA, Goodell GG. A confocal laser scanning microscope investigation of the epiphany obturation system. J Endod 2007;33:957-61.

9. Orstavik D. Essential endodontology: prevention and treatment of apical periodontitis: John Wiley \& Sons; 2020.

10. Zehnder M. Root canal irrigants. J Endod 2006;32:389-98.

11. Taşman F, Çehreli ZC, Oğan C, Etikan İ. Surface tension of root canal irrigants. J Endod 2000;26:586-7.

12. Abou-Rass M, Patonai FJ. The effects of decreasing surface tension on the flow of irrigating solutions in narrow root canals. Oral Surg Oral Med Oral Pathol Oral Radiol 1982;53:524-6.

13. Akcay M, Arslan H, Durmus N, Mese M, Capar ID. Dentinal tubule penetration of AH Plus, iRoot SP, MTA fillapex, and guttaflow bioseal root canal sealers after different final irrigation procedures: A confocal microscopic study. Lasers Surg Med 2016;48:70-6.

14. Byström A, Sundqvist G. Bacteriologic evaluation of the effect of 0.5 percent sodium hypochlorite in endodontic therapy. Oral Surg Oral Med Oral Pathol 1983;55:307-12.

15. Byström A, Sunvqvist G. The antibacterial action of sodium hypochlorite and EDTA in 60 cases of endodontic therapy. Int Endod J 1985;18:35-40.

16. Kokkas AB, Boutsioukis AC, Vassiliadis LP, Stavrianos CK. The influence of the smear layer on dentinal tubule penetration depth by three 
different root canal sealers: an in vitro study. J Endod 2004;30:100-2.

17. Violich D, Chandler $N$. The smear layer in endodontics-a review. Int Endod J 2010;43:2-15.

18. Wu L, Mu Y, Deng $\mathrm{X}$, Zhang $\mathrm{S}$, Zhou D. Comparison of the effect of four decalcifying agents combined with 60 C $3 \%$ sodium hypochlorite on smear layer removal. J Endod 2012;38:381-4.

19. Jardine AP, Da Rosa RA, Santini MF, et al. The effect of final irrigation on the penetrability of an epoxy resin-based sealer into dentinal tubules: a confocal microscopy study. Clin Oral Investig 2016;20:117-23.

20. Giardino L, Ambu E, Becce C, Rimondini L, Morra $M$. Surface tension comparison of four common root canal irrigants and two new irrigants containing antibiotic. J Endod 2006;32:1091-3.

21. Cameron JA. The effect of a fluorocarbon surfactant on the surface tension of the endodontic irrigant, sodium hypochlorite: a preliminary report. Aust Dent J 1986;31(5):364-8.

22. Calt $S$, Serper A. Time-dependent effects of EDTA on dentin structures. J Endod 2002;28:17-9.

23. Evcil MS, Ersoy İ, Yeter KY, Topcu KM. A comparison of the accuracy of two different apex locators usıng different root canal solutıons. J Dent Fac Ataturk Uni 2012:132-7.

24. Baumgartner JC, Mader CL. A scanning electron microscopic evaluation of four root canal irrigation regimens. J Endod 1987; 13:147-57.

25. Morgan LA, Baumgartner JC. Demineralization of resected root-ends with methylene blue dye. Oral Surg Oral Med Oral Pathol Oral Radiol Endod 1997;84:74-8.

26. Çiçek $E$, Keskin Ö. The effect of the temperature changes of EDTA and MTAD on the removal of the smear layer: a scanning electron microscopy study. Scanning 2015;37:193-6.

27. Hu X, Ling J, Gao Y. Effects of irrigation solutions on dentin wettability and roughness. J Endod 2010;36:1064-7.

28. Zehnder M, Paque F. Disinfection of the root canal system during root canal re-treatment. Endodontic Topics 2008;19(1):58-73.

29. Cury JA, Bragotto C, Valdrighi L. The demineralizing efficiency of EDTA solutions on dentin: I. Influence of $\mathrm{pH}$. Oral Surg Oral Med Oral Pathol 1981;52:446-8.

30. Pérez VC, Cárdenas MEM, Planells US. The possible role of $\mathrm{pH}$ changes during EDTA demineralization of teeth. Oral Surg Oral Med Oral Pathol 1989;68:220-2.

31. Serper A, Çalt S. The demineralizing effects of EDTA at different concentrations and $\mathrm{pH}$. J Endod 2002;28:501-2.

32. Eriksson A, Albrektsson T, Grane B, McQueen D. Thermal injury to bone: a vital-microscopic description of heat effects. Int J Oral Surg 1982;11:115-21.

33. Tuncer AK, Tuncer S. Effect of different final irrigation solutions on dentinal tubule penetration depth and percentage of root canal sealer. J Endod 2012;38:860-3.

34. Patel D, Sherriff M, Ford T, Watson T, Mannocci F. The penetration of RealSeal primer and Tubliseal into root canal dentinal tubules: a confocal microscopic study. Int Endod J 2007;40:67-71.

35. Carrigan PJ, Morse DR, Furst ML, Sinai IH. A scanning electron microscopic evaluation of human dentinal tubules according to age and location. J Endod 1984;10:359-63.

36. De Deus GA, Gurgel-Filho ED, Maniglia-Ferreira C, Coulinho-Filho $T$. The influence of filling technique on depth of tubule penetration by root canal sealer: a study using light microscopy and digital image processing. Aust Endod J 2004;30:23-8.

37. Kagayama M, Sasano $Y$, Sato $H$, Kamakura $S$, Motegi K, Mizoguchi I. Confocal microscopy of dentinal tubules in human tooth stained with alizarin red. Anat Embryol 1999;199(3):233-8.

38. Kok D, Duarte MAH, Da Rosa RA, Wagner $M H$, Pereira JR, Só MVR. Evaluation of epoxy resin sealer after three root canal filling techniques by confocal laser scanning microscopy. Microsc Res Tech 2012;75:1277-80.

39. De-Deus G, Brandao M, Leal F, et al. Lack of correlation between sealer penetration into dentinal tubules and sealability in nonbonded root fillings. Int Endod J 2012;45:642-51.

\author{
Sorumlu Yazarın Yazışma Adresi \\ Meltem Sümbüllü \\ Department of Endodontics, Faculty of \\ Dentistry, Ataturk University. \\ Erzurum, 25240, Turkey. \\ Phone: +90.442.231 1515 \\ Fax: +90.442 .2312270$ \\ E-mail: meltem endo@hotmail.com
}

